\title{
Identified at Death
}

National Cancer Institute

\section{Source}

National Cancer Institute. Identified at Death. NCI Thesaurus. Code C159690.

An indication that some condition was identified upon an individual's death. 